\title{
BETWEEN THEOLOGY AND ARCHAEOLOGY
}

\author{
George E. Mendenhall \\ Department of Near Eastern Studies \\ The University of Michigan \\ Ann Arbor, Michigan 48109
}

Between theology and archaeology there is a gulf fixed; so great a gulf is it that in comparison the two cultures of $C$. P. Snow seem but rivulets, minor tributaries in the canyon of academia. Any attempt to bring the two into some modus vivendi, however uneasy, is not an easy nor a comfortable undertaking, and it is only a profound conviction that the Bible will be understood in its own context by neither discipline in isolation that impelled me to make yet one more venture in producing a new synthesis.

It is not surprising that attacks from both directions appear in the articles of Professors Hauser and Thompson. In some respects the criticisms cancel out each other particularly in regard to the utilization of biblical traditions. Yet they do have much in common, derived from the simple fact that neither theology nor field archaeology as disciplines dealing with the far remote world of antiquity have exhibited much talent in historical matters, and often enough have affected a lofty disdain for "mere history." The task of historical reconstruction, however, is escalated to the point of impossibility when it is observed that even a most capable historian cannot $f$ ind satisfactory answers concerning the relationship between revolutionary movements and their accompanying ideologies in the recent past. The prime example is The Anatomy of Revolution of Crane Brinton. For Hauser's information, it was the work that first suggested that some such approach could 
be productive in understanding the historical process that eventually gave $r$ ise to both the $B$ ible as well as the evidence for radical change produced by excavation.

Some if not most of the arguments of both Hauser and Thompson have already been answered implicitly or explicitly in The Tenth Generation (hereafter, TTG), or in the recent re-statement and partial updating of the main arguments in Biblical Archaeologist 39 (December, 1976). All of Hauser's ten points are the result of his own failure to understand, irrelevant, or simply false, and there is no point (nor space) in taking up each one. There is a refreshing, even amusing, novelty in his triumphant discovery of my real sources in Marx, Rauschenbusch, and the ancient Greek philosophers, however. Unfortunately, my early education did not entail a reading of any of those particular worthies, and in any case it could hardly have occurred to me that they had anything to do with the realities of biblical history and thought. In fact, it would seem to me that a reasonably intelligent reading of TTG would show close. kinship between modern Marxist political ideologies and the ancient cult of power and fertility, of Baal and Asherah.

I must confess complete inability to understand Hauser's rejection of my insistence upon ethic as the content as well as the necessary consequence of the religious experience by alleging that it stems from the "social gospel" of Rauschenbusch. Some have alleged that Christian ethics have never really been integrated into theological systems, to say nothing of ecclesiastical power structures, to be sure, and perhaps Hauser does not regard love as an ethical experience. In any case the relationship between faith and ethic was no late invention of Rauschenbusch, and the allegation is simply absurd.

So far as the ancient Greek cyclic philosophy of history is concerned, one would think that a scholar with a doctorate even from a school of religion would be able to detect some minimal difference between an 
ancient speculative philosophy and a periodization of archaeological evidence that has been worked out by field archaeologists less than sixty years ago. The procedure of Hauser is essentially that of Frazer in comparative religion, of reaching conclusions on the basis of superficial and accidental formal similarities. ( 1 'm a bit surprised that 1 escaped the accusation of Freudianism too, on the ground of my discussion of sexual activities at Baal Peor.) The fact of repeated discontinuities, major and minor, is not in question; the multitude of dead languages and scripts that have to be dug up and deciphered is witness of but one type.

The discussion of the dynamics of the process is the issue that should be the subject of debate, and I must reject $v$ igourously any allegation of forcing it into a rigid, simplistic system. After all, several centuries of debate have raged concerning the "fall" of the Roman Empire, but now we have dozens of cultures and empires and several "dark ages" to work on. The observation of some process was already adumbrated by Albright in his essay, "Toward an Organismic Philosophy of History" (FSAC Ch. II), but on a much larger scale. The fact is that wherever we have available sources, we have texts illustrating or deploring the disintegration of social relationships, social institutions and moral standards, and often enough rapid turnover of power. The process is vividly described in the OT prophets, and 1 merely suggest that their success in predicting the consequences was historically no fluke. It is true that "conquest of his neighbor has always been a temptation for man..." but Hauser fails to see that is more virulently contagious than the Russian flu. At present, this observation is the only plausible means by which the civilizationwide destructions can be explained, once the age old deus ex machina has been ruled out.

It is rather unfortunate that both critics saw fit to attack only the motif of the "peasant's revolt," 
for this was, in my view, but an incidental and possibly even accidental aspect of the 'biblical revolution.' After all, peasant's revolts are a repeated phenomenon in the course of history, but rarely if at all do they have any significant lasting effect, quite in contrast to the early Israelite movement. For what was formed with great rapidity was a new and qualitatively different allegiance group, even though almost every specific formal trait of the group has not only a parallel, but also often a long and complex prehistory reaching far back into pre-lsraelite times. It is precisely this fact that virtually demonstrates my thesis that there can hardly have been any significant socio-cultural contrasts between the early lsraelite and non-lsraelite populations of Palestine in the early twelfth century B.C. The contrast that did surely exist was the same as that which characterized the Arabian peninsula in the early seventh century A.D., namely monotheists versus polytheists, apart from the recent arrivals with superior technology and military expertise such as the Philistines.

It is very difficult, if not impossible, for modern Western man to conceive of a new cultural synthesis stemming from a new religious ideology, just as it is virtually impossible to convince the usual secular university professor that religion has occasionally in the past functioned to create new and larger communities, rather than merely to create and perpetuate socio-cultural divisiveness. Yet there is for me at least no satisfying alternative that can account at all for the very diverse kinds of phenomena encountered in the biblical and archaeological sources. If is true that it was in fact an ideology that brought into existence that large society of ancient Israel, then it follows that archaeological evidence alone can do not much more than describe the external circumstances of the society. The further removed from material remains the problem, the less can archaeology furnish the solution. It can describe the technology utilized by the society and perhaps trace origins and history; it can suggest probabilities concerning social organization, 
but the further one moves from material to intangible aspects of reality, the less certain the results of archaeology alone, and this applies also even to the material evidence for historical events such as the LB ash layers. It is for this reason that archaeological evidence alone cannot produce a history, except for those to whom history is simply technology. Like most theologians, anthropologists have little concept of history, probably because the latter concept itse If is absent from the primitive cultures with which anthropology primarily deals. There is sad irony in the fact that historical narrative and religiously grounded ethic are two traits that characterize the biblical record in sharp contrast to extra-biblical pagan sources, but neither aspect of the biblical tradition has even been taken seriously in most theological systems.

It would seem obvious that all social organizations are characterized by an ideological bonding. I hasten to add that I use the term "ideological" not to refer to political propaganda systems from which the twentieth century has already suffered so much, but instead in the sense often used by anthropologists to designate the complex of intangible common understandings that characterize a culture. Among the most important ideological traits that seem to be universal are religion, morality, language, and law. The only possible bonding of the early lsraelite tribes that fits available evidence is the religious covenant, which, contrary to Thompson and many other critics, cannot be reduced to a mere literary form, and therefore merely $1 \mathrm{i}-$ terary formal arguments against it are irrelevant, particularly since the closest parallels come from a quite diverse culture and context. The structure of thought and obligation, the relation between past history and future obligation, the sanctions imposed by the divine world both positive and negative in the form of curses and blessings, are all present in the earliest biblical sources. They are found also in an Early Bronze Age text from Byblos, and I for one would not at all be surprised if much of this structure of ideological bonding should turn up in the Ebla texts. 
However, any gang of robbers can make a covenant. What needs to be understood is the structure and functioning of that ancient society, for 1 have doubts that it can ever be historically explained. There can be no reasonable doubt that all important aspects of their culture were closely linked to God, or to put it in secular terms were ideologically integrated about a single generative symbol that is difficult for modern man to conceive. In contrast to most ancient and modern covenants or treaties, that structure had a toughness that could survive even the formation of the state--and therefore long outlive it. The theology of the state was not, pace Thompson, a "revisionism" but a recidivism, as the prophets and the deuteronomic history alike pointed out. The population of the North evidently came to the same conclusion at the end of Solomon's reign.

All of the objections to the thesis of TTG that Hauser and Thompson bring stem simply from a failure to understand the structure and function of a federation of villages. There can be no doubt, in the first place that ancient Israel was a $v i l l a g e$ population and culture. It contrasted sharply on the one hand to the urban populations, not in material culture, nor even in language, but in ideology and ethic. On the other hand, it contrasted equally sharply to the steppe nomadic groups that by then did exist as distinct cultural entities, over against pastoralism as an occupational specialization within a culture or society.

There can be no doubt, further, that the wars were fought against the network of city states that had previously exercised control of the entire territory. Thompson's view of the city states is very naive. Though the Amarna letters may be vague to him, they are not to those who have studied them in depth. Archaeological surveys are superficial in both senses of the term, and no base for denying the fact of extended territorial control that is well illustrated in detail in the Amarna archives. Everyone agrees that in this early period we are dealing with very small 
population groups, and I myself insist upon the fact that there was migration into the region from the SyroAnatolian areas over many centuries, peaking probably in the Early Iron age. We have historical, onomastic, and linguistic evidence to prove it. But those migrations were no more "Israelites" than were the eighteenth and nineteenth century migrants to the new world "Americans."

Kenneth Boulding once remarked that economics is simply the art of fitting means to ends. Similarly law has been defined as the sum of community morality that judges find it practicable and expedient to uphold by the means of force. Both structures of social organization are thus merely instrumental toward ends that they themselves do not create, but merely presuppose. Idolatry in the ancient world was the elevation of such structures, man-made, to the status of ultimate concern, and thus regarded as determinants of history. Unfortunately, such ideologies are still popular now disguised as political philosophies or worse propaganda lines useful in the struggle for power. I find it most depressing to read Thompson's statement that "centralizing, peace-keeping forces were effectively involved in the settlement of Iron Age Palestine." It is a mighty act of faith in the power of Baal as the cause and determinant of history. 